\title{
"THE CLIMATE OF NOTHINGNESS"
}

Bayville, L.I., N.Y. Dear Sir: "The experience of nothingness, however, arises in original forms today. The literature of preceding generations comforts us that we are not alone, but it does not precisely define our state of soul" (Experience of Nothingness, p. 4). Bemard Murchland writes his review as if my interest were the history of nthilism, and the problematic defined by Europeans. My interests are, however, systematically epistemological, sustained through all my work, and American in context and definition. Those who think in the European style will have to alter their stardpoint in order to see what I am getting at.

In the first place, I give a very precise (and unusual) definition to the word "myth." X's myth (Murchland's, say) is X's "sense of reality." Myth is the selector governing what we experience, perceive, understand, value, do (pp. 23-25, 89-100). There is no possibility of nonmythical understanding. Secondly, I give a precise description of the experience of nothingness (pp. 4-8). It "is an experience, not a concept" (p. 4). "Nihilism is an ideological interpretation imposed on the experience of nothingness" (p. 13). 1 discuss the European ideol ogy thereof (pp, 10-I6). I discuss how the experience of nothingness has recently broken through various American serises of reality; especially the sense of reality as objectivity (pp: 16-44). I give Bemard Lonergan"s "drive to question" a personalistic, nonintellectualist character that he himself scarcely suggests (pp. 44-50). And I note how the experience of nothingness reported by Nietzsche, Dostoevsky, Sartre, Camus, Kierkegaard and others cannot arise apart from the fulfilment of precise subjective conditions (pp. 51 64).

In a word, I unmask the European ideology, and show how without a prior commitment to honesty and freedom and courage, no one can even have the experience. (Why do nihilists write books? Why do they espouse "courageous confrontation with terror, boredoin, helplessness," as. Murchland puts it, and why do they think that such an attitude-among all possible attitudes-clears the mind and arms the will with new resolution"?) I pull no rabbits out of the hat except those that "close, careful analysis". shows are there, in Nietzsche; Sartre, Camus and the others. Let the reader try to show otherwise. This is not 1883, or 1943. A more accurate view than that of older analyses and a fresh analysis of a new body of experience were called for

Finally, I do not accept the "fluid, fragmented self" that is "Fashionable today." (I despise the riotion of "absence," "Huidity," and self as kaleidoscope; whether it occurs as Rieff's "therapentic man," or Harvey Cox's "Iudic theology," or as couriter-culture romanticism.) But neither do I accept Murchland's sense that there really is "a centered self" which "underlies" social systems and moral reference. I wanted to steer clear of substantialistic images. Why? Because our experience of self, community, culture, and world calls for a different, more subtle, and more exact sort of terminology.

$\bullet$

In Belief and Unbelief (1965) I announced my purpose: to develop a philosophy of "intelligent subjectivity"; to invent a new language for speaking about the self. Sustained reflection suggests to me that the language of the Westem humanistic tradition points to important realities but states them badly. I want to replace the ethic of "principles" with an ethic of "stories" (pp. 23. 31 ); langiage about a "centered self" with my own definition of a language of "horizon"; the language of "depth" and "continuity" in reference to the self with the Ianguage of commitment to a drive, a complex dynamism, a set of operations.

I am a different man today from what I was ten years ago. Yet I remain faithful to what I was then, too; I am not "alienated" from my past. What sort of theory accounts for such an experience? Well, I can find no one center - image of a central, substantial core) in myself; I find no self that I "have" or "am." But I do remoin faithful now to the drive to question-to honesty, courage, freedom, community-the values I take pains to define in Experience of Nothingness. These values have a peculiar characteristic. They continually change their content. I would call them formal qualities, but "formal" is too static a word. So I define the self in terms of a set of operations which for their operating depend upon a world. "I am a conscious world, a horizon, a two-poled organism, a conscious, open-ended, protean, structuring of a world. The world exists through my consciousness and my consciousness through it: not two but one-in-act" (p. 55). I believe this view to be ancient rather than post-Enlightenment in its roots; I comment closely on Aristotle at some length (pp. 65-79, and extensive notes). But it is post-critical in its validity, strength, and fruitfulness. It meets the date of psychoanalysis, social science and ecology. It will perform all the functions of the "centered self" view, without its faulty substantialistic, individualistic, and alienating connotations. And it is, quite clearly, my answer to the "fashionable" worldviews in America which I despise at least as much as Murchland. : Michael Novak 